\title{
COMMENTS
}

\section{DEVELOPMENTS IN THE LAW: JUDICIAL REVIEW OF AGENCY RULEMAKING AND ADJUDICATION}

Section 706 of the Administrative Procedure Act (APA) provides for judicial review of rulemaking and adjudication by administrative agencies. ${ }^{1}$ Of the many developments in administrative law in the past decade, ${ }^{2}$ the judiciary's willingness to engage in genume, substantive review of agency determinations was one of the inost significant. Although the courts continued to recognize their general obligation to defer to agency decisions, ${ }^{3}$ they nevertheless resolved to examine administrative action much more closely than in years past. The United States Court of Appeals for the District of Columbia Circuit initiated this doctrine of more rigorous review, ${ }^{4}$ variously labelled the "substantial-inquiry,"s "close-scrutiny," or "hard-look"7 doctrine. 8 The

1. 5 U.S.C. $\$ 706$ (1976). That section states in relevant part:

To the extent necessary to decision and when presented, the reviewing court shall decide all relevant questions of law, interpret constitutional and statutory provisions, and determine the meaning or apphicability of the terms of an agency action. The reviewing court shall- . . (2) hold unlawful and set aside agency action, findings, and conclusions found to be-(A) arbitrary, capricious, an abuse of discretion, or otherwise not in accordance with law ... (E) unsupported by substantial evidence in a case subject to sections 556 and 557 of this title or otherwise reviewed on the record ....

2. For a good discussion of the developments in administrative law of the last decade, see $K$. Davis, Administrative Law Treatise $\$ 1: 9$ (2đ ed. 1978).

3. See, e.g., Ethyl Corp. v. EPA, 541 F.2d 1, (D.C. Cir.), cert. denied, 426 U.S. 941 (1976). "This standard [arbitrary and capricious ] . . . is a highly deferential one. It presumes agency action to be valid. . . [I]t forbids the court's substituting its judgment for that of the agency and requires affirmance if a rational basis exists for the agency's decision." Id at 34.

4. See Greater Boston Television Corp. v. FCC, 444 F.2d 841, 851 (D.C. Cir. 1970), cert. denied, 403 U.S. 923 (1971):

[The court's] supervisory function calls on the court to intervene not merely in case of procedural inadequacies, or bypassing of the inandate in the legislative charter, but inore broadly if the court becomes aware, especially from a combination of danger signals, that the agency has not really taken a "hard look" at the salient problems, and has not gennimely engaged in reasoned decisionmaking.

See also Ethyl Corp. v. EPA, 541 F.2d 1 (D.C. Cir.), cert. denied, 426 U.S. 941 (1976); International Harvester Co. v. Ruckelshaus, 478 F.2d 615 (D.C. Cir. 1973); Natural Resources Defense Council, Inc. v. Mortou, 458 F.2d 827 (D.C. Cir. 1972); Environmental Defense Fund v. Ruckelshaus, 439 F.2d 584 (D.C. Cir. 1971).

5. Citizens to Preserve Overton Park, Inc. v. Volpe, 401 U.S. 402, 415 (1971).

6. Sierra Club v. Froehlke, 359 F. Supp. 1289, 1363 (S.D. Tex. 1973), rev'd and remanded sub nom. Sierra Club v. Callaway, 499 F.2d 982 (5th Cir. 1974). 
Supreme Court appeared to adopt the hard-look doctrine in Citizens To Preserve Overton Park, Inc. v. Volpe, stating that judicial review of agency decisions entails "thorough, probing, in-depth review" even under the "arbitrary and capricious" standard of the APA. ${ }^{10}$ Commentators have praised the judiciary's creativity and willingness to supplement the bare procedural and substantive outlines of the APA. ${ }^{11}$ The Supreme Court's decision in Vermont Yankee Nuclear Power Co. v. National Resources Defense Council, Inc., with its sweeping dicta reproving this judicial initiative, ${ }^{12}$ failed to subdue enthusiasin for the hard-look doctrine. ${ }^{13}$ However, recent Supreme Court decisions have emphasized Vermont Yankee's narrow concept of the courts' role in reviewing agency decisions.

7. Kleppe v. Sierra Club, 427 U.S. 390, 410 n.21 (1976) (Powell, J.); Aberdeen \& Rockfish R.R. v. Students Challenging Regulatory Agency Procedures, 422 U.S. 289, 327 n.28 (1975); Culpeper League for Envtl. Protection v. NRC, 574 F.2d 633, 634 (D.C. Cir. 1978) (per curiam); Natural Resources Defense Council, Inc. v. Morton, 458 F.2d 827, 838 (D.C. Cir. 1972) (Leventhal, J.); Chautauqua County Envtl. Defense Council v. Adams, 452 F. Supp. 376, 380 (W.D.N.Y. 1978).

8. Rodgers, A Hard Look at Vermont Yankee: Environmental Law Under Close Scrutiny, 67 Geo. L.J. 699, 704 \& nn. 41-43, 705 (1979). Professor Rodgers views the hard-look doctrine as involving three components:

First is the substantive component, under which the courts read closely the operative statute to make sure the agencies stay within the scope of discretion assigned by Congress. Second is the procedural component, under which the courts have assumed a power to oversee the fairness of agency decisionmaking. . . .

Third, and most important, is the incessant demand of the hard-look case law for reasoned decisionmaking.

Id. at 705 (footnote onnitted).

9. 401 U.S. 402, 415 (1971). This "probing" review involved examination of the facts to determine whether the agency acted within its congressionally delegated "authority and discretion." That review also required the Court to determine whether the agency's decision "was based on a consideration of the relevant factors and whether there has been a clear error of judguncnt." Id. at 415-16.

10. 5 U.S.C. $\S 706$ (1976).

11. Davis, supra note 2, $\S 6: 1$. "Perhaps about nime-tenths of American administrative law is judge-1nade law, and the other teuth is statutory, but even the statutory portion is largely a codifcation of judge-made law." Id. § 2:18. "Formally, the chief element [in judicial decisions on administrative law] is interpretation of the APA, but realistically, the new law is judicially created and is usually more in the nature of common law than of finding what Congress intended in 1946." Id. § 6:1.

12. 435 U.S. 519 (1978). "Agencies are free to grant additional procedural rights in the exercise of their discretion, but reviewing courts are generally not free to inpose thein . . ." Id. at 524. "[N]othing in the APA . . . permitted the court to review and overturn the rulemaking proceeding on the basis of the procedural devices employed (or not employed) by the Commission so long as the Commission employed at least the statutory minima ...." Id. at 548 (italics in original).

13. DAvis, supra note 2, $\$ \S 6: 37,6: 37-1$ (Supp. 1980); Davis, Administrative Common Law and' the Vermont Yankee Opinion, 1980 UTAH L. REV. 3, 13-16; Rodgers, supra note 8, at 708 ("Upon analysis, it is safe to predict that the decision will be sharply contained."). 
This note examines the more significant developments of the past two years in judicial review of agency rulemaking and adjudication. Part I analyzes the Supreme Court's recent application of Vermont Yankee to justify its increasingly deferential attitude towards agency determinations. ${ }^{14}$ The analysis centers on the implications of this attitude for the administrative cominon law and section 559 of the APA. Part II discusses American Textile Manufacturers Institute $v$. Donovan, ${ }^{15}$ focusing on the unique problems that scientific issues pose for reviewing courts. ${ }^{16}$ Part III examines the Supreme Court's decision in FCC v. WNCN Listeners Guild, ${ }^{17}$ concentrating on the Court's extreme deference towards the agency, the effect of such deference on the case's final result, and the implications of the decision for future developments in judicial review. ${ }^{18}$

\section{The Perpetuation of Vermont YankeE's Derogation of THE ADMINISTRATION COMMON LAW}

With its statement that only in "extremely compelling circumstances" may courts impose procedural requirements on agencies in addition to those set forth in the APA, ${ }^{19}$ Vermont Yankee contradicted both the common law and section 559 of the APA. ${ }^{20}$ The case law supports the Court's observation that the judiciary should generally allow agencies to promulgate their own procedural rules within statutory bounds. ${ }^{21}$ However, the Supreme Court has frequently required agencies to develop procedures additional to those set forth in the APA. ${ }^{22}$

\footnotetext{
14. See notes 19-77 infra and accompanying text.

15. 101 S. Ct. 2478 (1981).

16. See notes $94-135$ infra and accompanying text.

17. 450 U.S. 582 (1981).

18. See notes 136-87 infra and accompanying text.

19. 435 U.S. $519,543(1978)$ at 543.

20. Section 559, 5 provides:

This subchapter and chapter $7 \ldots$ do not limit or repeal additional requirements imposed by statute or otherwise recognized by law. Except as otherwise required by law, requirements or privileges relating to evidenee or procedure apply equally to agencies and persons. Each agency is granted the authority neeessary to comply with the requirements of this subchapter through the issuance of rules or otherwise.
}

5 U.S.C. $\$ 559$ (1976).

21. 435 U.S. at 525, 543. See FPC v. Transcontinental Gas Pipe Lime Corp., 423 U.S. 326, 333 (1976); FCC v. Schreiber, 381 U.S. 279, 290 (1965); FCC v. Pottsville Broadcasting Co., 309 U.S. 134, 143 (1940); DAVIS, supra note 2, § 6:37.

22. See, e.g., Goss v. Lopez, 419 U.S. 565 (1975); Wolff v. McDonnell, 418 U.S. 539 (1974); Camp v. Pitts, 411 U.S. 138 (1973); Richardson v. Perales, 402 U.S. 389 (1971); United States v. Utah Constr. \& Mining Co., 384 U.S. 394 (1966); Morgan v. United States, 298 U.S. 468 (1936); DAvis, supra note 2, § 6:37 (Supp. 1980). But in Dunlop v. Bachowski, 421 U.S. 560 (1975), the Court based its imposition of additional procedural requirements on the statute, rather than on common law (called a "cautious approach" by one commentator. W. GELLHORN, C. BYSE \& P. 
Based on concepts of procedural and substantive justice rather than on statutory provisions, those decisions have become part of the vast administrative common law. ${ }^{23}$ Furthermore, the statement in section 559 that the APA does "not limit or repeal additional requirements imposed by statute or otherwise recognized by law" 24 directly contradicts the extremely limited standard of judicial review applied in Vermont Yankee. ${ }^{25}$ In two recent decisions, the Supreme Court failed to recognize these common law and statutory objections to the Vermont Yankee concept of judicial review.

\section{A. Strycker's Bay and its Misguided Reliance on Vermont Yankee.}

1. The decision. In Strycker's Bay Neighborhood Council, Inc. v. $K_{\text {Karlen }}{ }^{26}$ the Supreme Court addressed the question whether the Department of Housing and Urban Development (HUD) lad complied with the National Environmental Policy Act of $1969^{27}$ (NEPA) in approving a local agency's decision to construct a low-income housing project on the upper west side of Manhattan. A component of the "West Side Urban Renewal Plan" (the Plan), the project was part of an attempt to rejuvenate deteriorating neighborhoods "on an integrated

Strauss, Administrative LaW-CaSes and Comments 366 (7th ed. 1979)). See generally Gagnon v. Scarpelli, 411 U.S. 778 (1973); Morissey v. Brewer, 408 U.S. 471 (1972) (imposition of additional procedures to protect an individual's fundamental rights).

23. See note 11 supra.

24. 5 U.S.C. $\$ 559$ (1976)(emphasis added).

25. DAVIS, supra note $2, \S 6: 37$ (Supp. 1980). Professor Davis notes that section 12, the precursor of section 559, "recognized three kinds of law-constitutional law, statutory law, and common law, and provided that nothing in the APA shall be interpreted to cut back rights that stem from any one of the three kinds of law. . . . Of course, law that is neither constitutional nor statutory has to be common law." Id. See note 11 supra.

Section 559 is consistent with the general legislative history of the APA, which shows that the APA provides minimum, rather than maximum, procedural requirements. S. Doc. No. 248, 79th Cong., 2d Sess. 193, 217, 250 (1946). "The bill . . . is not a specification of the details of administrative proeedure, nor is it a codificarion of administrative law. Instead, . . . there has been framed an outline of minimum basic essentials." Id. at 193. Although the APA ensures a modicum of procedural regularity, it was by no means intended to preempt existing law.

The legislative history of section $\mathbf{5 5 9}$ accords with this notion: "Nothing in the bill is to diminish constitutional rights or limit or repeal additional requirements of law. The first sentence of [559] is intended simply to indicate that the act will be imterpreted as supplementing constitutional and legal requireinents imposed by existing law." Id. at 215, 281.

Professor Davis also notes that the Supreme Court in Vermont Yankee, counsel in that case, and numerous commentators seemed unaware of the effect or even the existenee of section 559. DAVIS, supra note 2, $\S 6: 37$ (Supp. 1980). Indeed, judging from the scant case law dealing with section 559, few have recognized its significanee.

26. 444 U.S. 223 (1980).

27. 42 U.S.C. $\S 4321-4361$ (1976). 
basis both racially and economically."28 The Plan originally designated the site at issue, "Site 30, " as the future location of a middlemcome housmg project. However, upon its determination that there existed an insufficient number of low-income projects, the New York City Planning Commission redesignated Site 30 for low-mcome housing. HUD approved this change and, in a suit brought by individuals and a local school to prevent the construction of low-mcome housing on Site 30, a federal district court affirmed HUD's decision. ${ }^{29}$ The court of appeals reversed, holding that HUD had failed to satisfy NEPA's requirement that an agency 'study, develop, and describe appropriate alternatives to recommended courses of action in any proposal which involves unresolved conflicts concerning alternative uses of available resources." 30 The court stated that $\mathrm{m}$ hight of the "urban environmental factors" involved and the substantial, long-term effect that the housing project would have on the Plan's goal of racial and economic integration, the situation required a study $\mathrm{m}$ accordance with the NEPA requireinent. ${ }^{31}$

On reinand, HUD compiled a report entitled "Special Environmental Clearance" (the Report) which considered the arguments for and against committing Site 30 entirely to low-mcone housing. Although the Report identified two other sites as environmentally superior to Site 30 for such housing, HUD concluded that the possibility of a two-year delay resulting from building the low-mcome project at either of the alternate sites outweighed the environmental benefits that would result from such action. Finding that HUD's decision was "neither arbitrary nor capricious," the district court affirmed. 32

The court of appeals once agam reversed the district court. The court emphasized the "substantive standards" embodied in NEPA, the drainatic and lasting environmental impact that the project would have on the neighborhood, and the Report's finding that other sites were enviroumentally superior to Site 30 for low-mcome housing. The court concluded:

Congress, in authorizing federal aid and creating HUD itself, had exactly 'social environmental impact' in mind as expressed in [NEPA] . . . Therefore . . . we hold that delay is not to be re-

28. Karlen v. Harris, 590 F.2d 39, 41 (2d Cir. 1978), rev'd sub nom. Strycker's Bay Neighborhood Council, Inc. v. Karlen, 444 U.S. 223 (1980).

29. Trinity Episcopal School Corp. v. Romney, 387 F. Supp. 1044 (S.D.N.Y. 1974), rev'd and remanded, 523 F.2d 88 (2d Cir. 1975).

30. 42 U.S.C. $\$ 4332(2)$ (E) (1976).

31. Trinity Episcopal School Corp. v. Romney, 523 F.2d 88, 93-94 (2d Cir. 1975).

32. Trinity Episcopal School Corp. v. Harris, 445 F. Supp. 204, 220 (S.D.N.Y.), rev'd and remanded sub nom. Karlen v. Harris, 590 F.2d 39 (2d Cir. 1978). 
garded as an overriding factor and that environmental factors, such as crowding low-incoine housing into a concentrated area, should be given determinative weight. ${ }^{33}$

The Supreme Court reversed in a per curiam opinion. The Court quoted the Vermont Yankee proposition that NEPA establishes "essentially procedural" requirements. If an agency has fulfilled NEPA's procedural requirements, the reviewing court's role is restricted to ensuring that the agency has considered the environmental consequences of its action. ${ }^{34}$ In judging whether the agency has "considered" environmental factors, a court may not substitute its own preferences for those of the agency. ${ }^{35}$ The Court summarily concluded that HUD had im fact "considered" the environmental implications of its decision and held that "NEPA requires no more."36

2. The misapplication of Vernont Yankee. Strycker's Bay is objectionable for two reasons. First, the Court failed to examine the validity of HUD's conclusions as set forth in the Special Environmental Clearance. Generally, a reviewing court must determine whether the agency's conclusions are "irrational" witl regard to the facts and the relevant statutory criteria. ${ }^{37}$ The Court's justification for refusing to engage in this imquiry-reliance on the Vermont Yankee dicta restrictmg the scope of judicial review ${ }^{38}$-is the second objection to Strycker's Bay. Although an agency's decision is entitled to a presumption of regularity, ${ }^{39}$ this presuinption by no means excuses a court's failure to scrutinize the substance of the agency's conclusions. ${ }^{40}$

Concerning the first objection to Strycker's Bay, the purpose of the Plan- "to create a racially and econounically imtegrated cominumity"41 - must be emphasized. To achieve the Plan's goals, those selecting the sites for middle- and low-income housing projects liad to give

33. Karlen v. Harris, 590 F.2d 39, $43-44$ (2d Cir. 1978), rev'd sub nom. Strycker's Bay Neighborhood Council, Inc. v. Karlen, 444 U.S. 223 (1980).

34. Strycker's Bay Neighborhood Council, Inc. v. Karlen, 444 U.S. 223, 227 (1980).

35. Id. at $227-28$.

36. Id. at 228.

37. Verkuil, Judicial Review of Informal Rulemaking: Waiting for Vermont Yankee II, 55 TUL. L. REv. 418 (1981). The determination of whether the agency's conclusions are "irrational" comes within the "arbitrary and capricious" standard of review even under a limited notion of that standard. Id. at 422, 423 \& n.21. See Saginaw Broadcasting Co. v. FCC, 96 F.2d 554 (D.C. Cir. 1938) (describing proper fact-finding by an agency). The last steps of the fact-finding process are the agency's inferring "ultimate" facts from the evidence on the basis of statutory language and then making a decision from the findings that follows statutory criteria. Id. at 559. See generally Industrial Union Dep't v. Hodgson, 499 F.2d 467, 473 (D.C. Cir. 1974).

38. Strycker's Bay Neighborhood Council, Inc. v. Karlen, 444 U.S. 223, 227 (1980).

39. Citizens to Preserve Overton Park, Inc. v. Volpe, 401 U.S. 402, 415 (1971).

40. Id. (the presumption should not prevent a "thorough, probing, in-depth rcview").

41. See text accompanying note 41 supra. 
primary consideration to social environmental factors. Locating lowmcome housing im neighborhoods already pervaded by similar housing would frustrate the Plan. No one disputed the character of the neighborhood surrounding Site 30. The court of appeals noted that the briefs of both parties showed that at least one inajor street in the area was "lined with low-income housing."42 Furthermore, HUD itself found two locations, Sites 9 and 41, environmentally superior to Site 30 for new low-mcome housing. ${ }^{43}$ Given the social and environmental purpose of the Plan, and also given that a low-income housing project, if built in a low-imcome neighborhood, would determine the economic and racial character of the area for the life of the structure, ${ }^{44}$ HUD's decision is at best questionable.

The decision is also questionable in light of the "applicable statutory criterion." 45 The broad statements in NEPA mandating responsible governmental action with respect to the environment ${ }^{46}$ demonstrate not only Congress's desire to protect the environment, but, arguably, a congressional preference for resolving uncertainty in a manner further-

42. Karlen v. Harris, 590 F.2d 39, 43 (2d Cir. 1978), rev'd sub nom. Strycker's Bay Neighborhood Council, Inc. v. Karlen, 444 U.S. 223 (1980).

43. $I d$. at 42.

44. Id. at 44. See generally 42 U.S.C. $\$ 4331$ (b)(1) (1976) (requiring the federal government to use resources "as trustee of the environment for succeeding generations").

45. Saginaw Broadcasting Co. v. FCC, 96 F.2d 554 (D.C. Cir. 1938). See note 37 supra and accompanying text.

46. 42 U.S.C. $\$ 4331$ (1976). Subsection (b) of section 4331 provides:

(b) In order to carry out the policy set forth in this cliapter[ policies and goals of NEPA], it is the continuing responsibility of the Federal Government to use all practicable means, consistent with other essential considerations of national policy, to improve and coordinate Fcderal plans, functions, programs, and resources to the end that the Nation inay-

(1) fulfill the responsibilities of each generation as trustee of the environment for succeeding generations;

(2) assure for all Americans safe, healthful, productive, and esthetically and culturally pleasing surroundings;

(3) attain the widest range of beneficial uses of the environment without degradation, risk to health or safety, or other undesirable and unintended consequences;

(4) preserve important historic, cultural, and natural aspects of our national heritage, and maintain, wherever possible, an environment which supports diversity and variety of individual choice;

(5) achieve a balance between population and resource use which will permit high standards of living and a wide sharing of life's amenities; and

(6) enhance the quality of renewable resources and approach the inaximum attainable recycling of depletable resources.

42 U.S.C. $\$ 4332$ requires that the "policies, regulations, and public laws of the United States" be interpreted and applied to conform with NEPA. That section also provides that all agencies develop methods and procedures for furthering environmental goals, prepare detailed environmental impact statements for any action substantially affecting the environment, and study and describe alternatives to decisions that involve unresolved issues concerning the environment. 42 U.S.C. $\S 4332(B),(C),(E) .42$ U.S.C. $\$ 4333$ requires agencies to review their existing policies and procedures to ensure that they implement environmental goals. 42 U.S.C. $\S 4331$ (b) (1976). 
ing environmental goals. ${ }^{47}$ Despite suggestions to the contrary in Strycker's Bay, ${ }^{48}$ NEPA does enbody significant substantive criteria. ${ }^{49}$

Furthermore, "NEPA litigation with substantive aims rarely proceeds without the supporting presence of compleinentary federal legislation supplying an unmistakeable substantive component."so If NEPA's substantive provisions, standing alone, failed to provide the statutory criteria for judging the rationality of HUD's decision, then the Fair Housing Act provided the added substantive coinponent necessary to coinpel substantive, as well as procedural, review. ${ }^{51}$ The Court's failure to examine the substance of HUD's conclusions violates the precept that a court must examine an agency's determinations in light of the context and purpose of the applicable statutes. ${ }^{52}$

The second objection to Strycker's Bay is the Court's justification for refusing to examine the substantive validity of HUD's decision. The Court resorted to the broad dicta of Vermont Yankee that discourages active judicial review. ${ }^{53}$ Reliance on Vermont Yankee is misguided for two reasons: first, the actual loolding of Vermont Yankee is

47. Trubek, Allocating the Burden of Environmental Uncertainty: The NRC Interprets NEPA's Substantive Mandate, 1977 WIs. L. Rev. 747, 748, 763; cf. McGarity, Substantive and Procedural Discretion in Administrative Resolution of Science Policy Questions: Regulating Carcinogens in EPA and OSHA, 67 GEo. L.J. 729, 784 (1979) (contending that the Occupational Safety and Health Act's broad statements advocating employee safety indicate congressional intent that agencies should err on the side of safety).

48. 444 U.S. at 227-28.

49. Vermont Yankee Nuclear Power Corp. v. National Resources Defense Council, Inc., 435 U.S. 519, 558 (1978) ("NEPA does set forth significant substantive goals for the Nation. . ."); Kleppe v. Sierra Club, 427 U.S. 390, 409-10 (1976); Rodgers supra note 8, at $708 \mathrm{nn} .75 \&$ 76, 710. For examples of these substantive criteria, see note 40 supra.

50. Rodgers, supra note 8, at 710-11. Professor Rodgers cites Citizens to Preserve Overton Park, Inc. v. Volpe, 401 U.S. 402 (1971), as a significant example of this phenomenon. Plaimtiffs in that case based their winning arguments on NEPA and the Federal-Aid Highway Act of 1968, Pub. L. No. 90-495, § 18(a), 82 Stat. 823 (1968) (current version at 23 U.S.C. $§ 138$ (1976)).

51. 42 U.S.C. $\$ \$ 3601,3608$ (1970). In Karlen v. Harris, the Court of Appeals for the Second Circuit recognized the force that the Fair Housing Act adds to NEPA, stating:

An additional source of the affirmative duty to integrate is found in the 1968 Fair Housing Act . . . which provides that "[i]t is the policy of the United States to provide, within constitutional limitations, for fair housing throughout the United States," 42 U.S.C. $\S 3601$ and, in $\S 3608$, that "(d) The Secretary of Housing and Urban Development shall ... (5) administer the programs and activities relating to housing and urban development in a manner affirmatively to further the policies of this sub-chapter."

590 F.2d at 45 (quoting Otero v. New York City Hous. Auth., 484 F.2d 1122, 1133 (2d Cir. 1973). This argument assumes that segregated housing results in unequal housing. The Supreme Court's reasoning in the landinark case of Brown v. Board of Educ., 347 U.S. 483 (1954), was based on a similar assumption.

52. See NLRB v. Highland Park Mfg. Co., 341 U.S. 322, 325 (1951).

53. Strycker's Bay Neighborhood Council, Inc. v. Karlen, 444 U.S. 223, $227-28$ (1980). In Sirycker's Bay the Court quoted froin and relied heavily on Vermont Yankee. It stated that 'NEPA . . . imposes upon agencies duties that are 'essentially procedural.' . . . [O]nce an agency has made a decision subject to NEPA's procedural requirements, the only role for a court is to 
narrow; and second, the Strycker's Bay Court distorted both the holding and dicta of Vermont Yankee.

The narrowness of the Vermont Yankee holding is demonstrated by the Court's own view of the issue presented in that case. Justice Rehnquist wrote for the Court: "After a thorough exmamation of the [lower court] opinion itself, we conclude that while the matter is not entirely free from doubt, the majority of the Court of Appeals struck down the rule because of the perceived inadequacies of the procedures employed in the rulemaking proceedings." 54 Thus, the Vermont Yankee Court treated the issue as one of procedure, and the broad statements restricting judicial review should be read in light of the narrow procedural context of the case. 55

In contrast, Strycker's Bay presented a primarily substantive question, namely, whether HUD's approval of Site 30 for low-mcome housing was "arbitrary or capricious" with regard to NEPA. The Court demanded that the agency "consider" the relevant environmental factors but reduced "consideration" to a procedural requirement. HUD's mere presentation of the Special Environmental Clearance report satisfied the Court. However, "consideration" involves the qualitative weighing of facts and conclusions. To ensure that an agency has actually "considered" environmental factors, the court itself must examine the reasonableness of the agency's conclusions. In Strycker's Bay, the Court made no such imquiry; in asserting that Vermont Yankee was controlling, the Court reduced NEPA's requirement of qualitative consideration of environmental factors to a requirement that the agency merely note the existence of arguments opposing its conclusion. ${ }^{56}$

In sum, given the very different contexts and issues of the two cases, Vermont Yankee was of limited relevance to Strycker's Bay. By misconstruing the holding of Vermont Yankee, the Strycker's Bay Court perpetuated the most dangerous implications of Vermont Yankee. Vermont Yankee's derogation of administrative common law and failure to consider section 559 prompted many critics to predict that the

insure that the agency has considered the environmental consequences. . . " Id. at 227. See note 12 supra for the Vermont Yankee dicta explicitly restricting the scope of judicial review.

54. 435 U.S. at 540-41.

55. DAvis, supra note 2, $\$ \$ 6: 35-6: 36$. Commentators praised the holding that formal procedures normally need not be used in note and comment rulemaking proceedings. E.g. DAvis, supra note $2, \S 6: 37$ ("The Court's main accomplishment . . . was probably the further strengthening of the law that trial procedure (what the Court called 'adjudicatory procedure') is generally undesirable for rulemaking").

56. Cf. Rodgers, supra note 8 , at 708 (viewing NEPA as authorizing rigorous judicial review of substantive issues). 
case would have limited effect. 57 Whether Vermont Yankee represented a tendency to refrain from probing substantive and procedural review was unclear. ${ }^{58}$ In uncritically applying Vermont Yankee to Strycker's Bay, the Court disregarded both the hard-look doctrine and passages of Vermont Yankee that demand substantive review under NEPA. ${ }^{59}$ As a result, the Court limited substantive judicial review of administrative decisions beyond even the narrow Vermont Yankee concept of review.

\section{B. Steadman v. SEC: The Court's Failure to Follow the Letter and Spirit of Section 559.}

Steadman v. $S E C^{60}$ further demonstrates the Supreme Court's willingness to afford extreme deference to agency procedures and determinations. In Steadman, the Court upheld the Security and Exchange Commission's use of a preponderance-of-the-evidence standard of proof in proceedings concerning alleged antifraud violations. Unlike Strycker's Bay, the Court's decision in Steadman apparently rehed hittle on the restrictive judicial-review dicta of Vermont Yankee. Nonetheless, the same attitude and analysis that produced Vermont Yankee and Strycker's Bay also fashioned Steadman. As in the two earlier cases, the Court in Steadman failed to consider section 559 and consequently neglected common law principles vital to the correct resolution of the case.

Steadman involved a proceeding pursuant to section $9(\mathrm{~b})$ of the Investment Company Act of $1940^{61}$ and section 203(f) of the Investment Advisers Act of 1940.62 The SEC found by a preponderance of

57. See note 13 supra and accompanying text. See also DAvis, supra note $2, \S 6: 36$.

58. See Verkuil, supra note 37 , at 424.

59. Strycker's Bay Neighborhood Council, Inc. v. Karlen, 444 U.S. 223, 229-31 (1980) (Marshall, J., dissenting). See Vermont Yankee Nuclear Power Co. v. NRDC, 435 U.S. 519, 558 (1978).

60. 450 U.S. 91 (1981).

61. 15 U.S.C. $\& 80 a-9(b)$ (1976). Section 9 (b) provides that the SEC may, in certain circumstanees,

after notice and opportunity for hearing . . . prohibit, conditionally or unconditionally, either permanently or for such period of time as it in its discretion shall deein appropriate in the public interest, any person from serving or acting as an employce, officer, director, member of an advisory board, investinent adviser or depositor of, or principal underwriter for, a registercd investment company or affiliated person of such invcstment Id.

adviser, depositor, or primcipal underwriter. . . .

62. 15 U.S.C. $\$ 80 \mathrm{~b}-3(f)$ (1976). That section provides that the Commission, after notice and opportunity for hearing on the record, inay "censure or place limitations on the activities of any. person associated or seeking to become associated with an investuncnt adviser, or suspend for a period not exeeeding twelve months or bar any such person from being associated with an investment adviser." 
the evidence that petitioner Steadman had violated the antifraud provisions of the federal securities laws. ${ }^{63}$ As a result, the Commission permanently barred Steadman from the securities profession, forced him to sell the stock of his corporation at a significant loss, and prohibited him from associating with any securities broker or dealer for one year. ${ }^{64}$ Steadman appealed on the ground that such severe penalties required the SEC to prove its allegations of fraud by clear and convincing evidence, rather than by a preponderance of the evidence. The Court of Appeals for the Fifth Circuit upheld the Commission's use of the less demanding standard of proof. 65

The Supreme Court affirmed, stating that a court must abide by the "rules of evidence and standards of proof" that Congress prescribes for administrative proceedings. ${ }^{66}$ After analyzing the language and legislative history of section 556(d) of the APA, ${ }^{67}$ the Court held that Congress had established "preponderance of the evidence" as the stan-

63. The provisions violated were 15 U.S.C. $\$ \S 77 q(a), 78 j(b), 80 \mathrm{~b}-6(1)-(2)(1976)$.

64. 450 U.S. at $94 \&$ n.8.

65. Steadman v. SEC, 603 F.2d 1126 (5th Cir. 1979). The Steadman decision conflicted with two cases decided by the Court of Appeals for the District of Columbia Circuit. Whitney v. SEC, 604 F.2d 676 (D.C. Cir. 1979); Collins Securities Corp. v. SEC, 562 F.2d 820 (D.C. Cir. 1977).

66. 450 U.S. at 95 .

67. 5 U.S.C. § 556(d) (1976) provides:

Except as otherwise provided by statute, the proponent of a rule or order has the burden of proof. Any oral or documentary evidence may be received, but the agency as a matter of policy shall provide for the exclusion of irrelevant, immaterial, or unduly repetitious evidence. A sanction may not be imposed or rule or order issued except on consideration of the whole record or those parts thereof cited by a party and supported by and in accordance with the rehiable, probative, and substantial evidence.

The Steadman Court imterpreted "substantial evidence" as requiring that a sanction must rest on a "minimum quantity of evidence." 450 U.S. at 98 (emphasis in original). Furthermore,

[t]he additional words "in accordance with" suggest that the adjudicating agency must weigh the evidence and decide, based on the weight of the evidence, whether a disciplinary order should be issued. The language of [section 566(d)], therefore, requires that the agency decision must be "in accordance with" the weight of the evidence. . . . Obviously, weighing evidence has relevance only if the evidence on each side is to be measured against a standard of proof which allocates the risk of error.

450 U.S. at 99 (footnotes omitted).

Although the statute itself failed to suggest the applicable standard, the legislative history furnished guidance. "Where there is evidence pro and con, the agency must weigh it and decide in accordance with the preponderance." H.R. REP. No. 1980, 79th Cong., 2d Sess. 37 (1946). But see note 74 infra.

The SEC's consistent use of this standard of proof in antifraud proceedings further supports the Court's decision to uphold the Commission's practice. 450 U.S. at 103-04. See In re Cea, 44 S.E.C. 8, 25 (1969); In re Pollisky, 43 S.E.C. 458, $459-60$ (1967); In re White, 3 S.E.C. 466, 539-40 (1938). See generally E.I. du Pont de Nemours Co. v. Collins, 432 U.S. 46, 54-55 (1977) (a reviewimg court must follow a consistent administrative construction of a statute " "unless there are compelling indications that it is wrong" " (quoting Red Lion Broadcasting Co. v. FCC, 395 U.S. 367, 381 (1969))). 
dard applicable in proceedings governed by section $556(\mathrm{~d}){ }^{68}$

Because the sanctions imposed on Steadman resulted in substantial injury to both his reputation and his property, his argument for the more rigorous standard of proof had merit. Criminal penalties such as fines or probation may be imposed only if the evidence satisfies the reasonable-doubt standard, but the SEC imposed much more injurious penalties on the petitioner even though the evidence might have raised significant doubts concerning his guilt. ${ }^{69}$ On its face, however, the Court's statutory argunent appeared to preclude any consideration of policy. Embodymg as it did the congressional will, the statute seemingly rendered "mapposite" Steadman's policy arguments. ${ }^{70}$

In construmg section 556(d) as it pertams to SEC antifraud proceedings, however, the Court failed to consider the implications of section 559. Section 559 states that the APA does not "limit or repeal additional requirements imposed by statute or otherwise recognized by law."71 As Justice Powell recognized in his dissent, Steadman based his policy arguments on the common law of fraud. ${ }^{72}$ Because sanctions imposed for fraud are so harsh, those attempting to prove fraud must do so by clear and convincing evidence-they, rather than the accused who has so much at stake, bear the risk of error. ${ }^{73}$ Congress, by enacting section 556(d), neither limited nor repealed the common law requirement that clear and convincing evidence be offered to prove fraud. By virtue of section 559, the specific common law rule preempts the general, less demanding provision of the APA. Congress did not intend to supplant the common law standard of proof when it enacted the Investinent Company Act or the Investment Advisers Act. Although Justice Powell failed to recognize the significance of section 559 , that section supports his conclusion that "[i]n the absence of any

68. 450 U.S. at 95-102 (1981). For another example of the Court's deference to the SEC, see Rubin v. United States, 449 U.S. 424 (1981).

69. 450 U.S. at 105-06 (Powell, J., dissenting).

70. Id. at 96 n. 10 .

71. 5 U.S.C. $\$ 559$ (1976). The term "otherwise recognized by law" includes the common law. See notes 11 and 25 supra.

72. "Sanctions imposed under these sections are the functional equivalent of penalties for fraud. At common law, it was plain that allegations of fraud had to be proved by clear and convincing evidence." 450 U.S. at 105 (Powell, J., dissenting). See generally Note, The Burden of Proof in SEC Disciplinary Proceedings: Preponderance and Beyond, 49 FORDHAM L. REv. 642 (1981) (arguing that the severe fraud penalties imposed by the SEC require the "clear and convincing" standard of proof as a inatter of procedural due process).

73. See, e.g., Addington v. Texas, 441 U.S. 418, 424 (1979) (dieta); Woodby v. Immigration \& Naturalization Serv., 385 U.S. 276, 285 n.18 (1966); Weininger v. Metropohtan Fire Ins. Co., 359 Ill. 584, 598, 195 N.E. 420, 426 (1935); Bank of Pocahontas v. Ferimer, 161 Va. 37, 40-41, 170 S.E. 591, 592 (1933) ("clear and satisfactory"); Bowe v. Gage, 127 Wis. 245, 251, 106 N.W. 1074, 1076 (1906) ("clear and satisfactory"). 
specific demonstration of Congress' purpose, we should not assume that Congress intended the SEC to apply a lower standard of proof than the prevailing common law standard for similar allegations."74

By acquiescing in the SEC's "preponderance of the evidence" standard of proof, the Supreine Court perpetuated Vermont Yankee's failure to recognize that section 559 integrates the common law into the APA. In Steadman, unlike in Vermont Yankee, a specific common law rule applied directly to the issue. Therefore, the Steadman Court's failure to consider the common law is even more inexcusable than the Court's unnecessary and inaccurate dicta in Vermont Yankee. ${ }^{75}$

In addition, relying expressly on Vermont Yankee, the Court held that the "preponderance" standard applies to all proceedings governed by section 556 (d). ${ }^{76}$ This lolding is clearly overbroad if section 559 is to have any ineaning. By providing that constitutional, statutory, and common law pertaining to the subject matter should apply notwithstanding section 556(d), section 559 shows that a preponderance of the evidence standard of proof may well not satisfy the statute.

\section{Deference to Agency Determinations: Other Cases.}

Other recent Supreine Court cases dealing with agency action einbody the limited scope of review found in Strycker's Bay and Steadman. In FTC v. Standard Oil Co. of California ${ }^{77}$ the Federal Trade Commission (FTC) charged that Standard had engaged in unfair and deceptive commercial practices. ${ }^{78}$ Standard sued to compel dismissal of the FTC complaint, alleging that the FTC had no "reason to beheve" that the company had violated the law.79 Reversing the Court of Appeals for the Ninth Circuit, the Supreme Court held that the decision to issue a complaint is not reviewable. The Court characterized the FTC complaint as a inere threshold determination, rather than a final agency decision. ${ }^{80}$ Judicial review of preliminary agency action such as the coinplaint at issue would interfere with the agency's

74. 450 U.S. at 106 (Powell, J., dissenting). One brief isolated statement in the legislative history of section 556(d) does call for a decision "in accordance with the preponderance." See note 62 supra. The Court should have discussed whether Congress manifested a specific intention to override the common law and the unequivocal statutory provisions of section 559 by this brief, isolated statement in the legislative history.

75. See notes 12, 19-25 supra and accompanying text.

76. 450 U.S. at 104.

77. 449 U.S. 232 (1980).

78. Id. at $243 \&$ n.2 See 15 U.S.C. $\$ 45$ (1976).

79. 449 U.S. at 235.

80. Id. at 238. 
proper function. ${ }^{81}$ The Court yielded to this pragmatic consideration at the cost of rendering the FTC's action virtually unreviewable. ${ }^{82}$

Haig v. Agee ${ }^{83}$ presents another example of the Court's growing tendency to defer to agency action. Agee, a fornner agent of the Central Intelligence Agency (CIA), began in 1974 a campaign to expose CIA agents and officers. In 1979 the Secretary of State revoked Agee's passport pursuant to a regulation allowing such action if the traveller's "activities abroad are causing or are likely to cause serious danage to the national security or the foreign pohicy of the United States."

The Supreme Court reversed the lower courts and upheld the Secretary's action. The controlling cases, Zemel v. Rusk ${ }^{85}$ and Kent v. Dulles, ${ }^{86}$ dictated that the Secretary show Congress had approved the regulation either by express delegation or by implied approval of a substantial and consistent administrative practice. ${ }^{87}$ Although the Secretary could point to fewer than six passport revocations based on national security, ${ }^{88}$ the Court found that Congress had acquiesced in the Secretary's consistent interpretation of the apphicable statute ${ }^{89}$ and its precursors. ${ }^{90}$ The dissent argued that $Z$ emel and Kent's requirement of a substantial and consistent practice was not satisfied by inere statutory construction. ${ }^{91}$ Although the literal language of those cases in fact called for consistent administrative practice,, 92 the Court deferred to the Secretary's broad reading of Zemel and Kent.

New legislation could dramatically reverse the Court's increasing deference to agency determinations. Two senate bills amend section 706 of the APA by requiring that the reviewing court inake no presumption in favor of agencies on questions of law. ${ }^{93}$ These revolutionary bills, if passed, would drastically undercut the principle that courts must generally defer to agencies.

81. Id. at 242.

82. Id. at 249 (Stevens, J., concurring in the judgment).

83. 101 S.Ct. 2766 (1981).

84. 22 CFR $\S 51.70(b)(4)$ (1981).

85. 381 U.S. 1 (1965).

86. 357 U.S. 116 (1958).

87. 49 U.S.L.W. at 4872.

88. 49 U.S.L.W. at 4875.

89. 22 U.S.C. $\$ 211 \mathrm{a}(1976)$.

90. 49 U.S.L.W. at $4872-75$.

91. Id. at 4878-80, $4880 \mathrm{nn} .9$ \& 10 (Brennan, J., dissenting).

92. Zemel v. Rusk, 381 U.S. 1, 12 (1965); Kent v. Dulles, 357 U.S. 116, 124-25 (1958).

93. S. 67. 96th Cong., 2d Sess. (1980); S.1080. 96th Cong., 2d Sess. (1980). 


\section{The Cotton Dust Case: Scientific Uncertainty, Cost \\ Benefit ANalysis, and the Need for Clear EXPRESSION OF CONGRESSIONAL POLICY}

In American Textile Manufacturers Institute, Inc. v. Donovan (Cotton Dust), ${ }^{94}$ the Supreme Court resolved a question presented in the preceding term by Industrial Union Department, AFL-CIO v. American Petroleum Institute (Benzene). ${ }^{95}$ The Court held in Cotton Dust that section 6(b)(5) of the Occupational Safety and Health Act of 1970 (the Act $)^{96}$ does not require the Secretary of Labor to show a reasonable relationship between costs and benefits in issuing regulations to limit exposure to toxic substances. In upholding the agency's conclusions and statutory construction, the Court conformed with the deferential attitude described in Part I of this note. ${ }^{97}$

\section{A. The Cost-Benefit Question.}

In the Benzene case, the Occupational Safety and Health Administration (OSHA), pursuant to section $6(\mathrm{~b})(5)$ of the Act, had promulgated standards that lowered the permissible employee exposure to benzene from ten parts benzene per million parts of air (ppm) to one ppin. The Court struck down the standards but declined to decide whether OSHA must demonstrate that the benefits of such a health standard are worth its costs. The Court based its decision on OSHA's failure to meet the threshold showing imposed by section 3(8),98 that an exposure of $10 \mathrm{ppm}$ of benzene constitutes a significant health threat.99

94. 101 S. Ct. 2478 (1981).

95. 448 U.S. 607 (1980).

96. Occupational Safety and Health Act $\S 6(b)(5), 29$ U.S.C. $\S 655(b)(5)$ (1976). Section $6(\mathrm{~b})(5)$ provides:

The Secretary, in promulgating standards dealing with toxic materials or harmful physical agents under this subsectiou, shall set the standard which most adequately assures, to the extent feasible, on the basis of the best available evidence, that no employee will suffer material impairment of health or functional capacity even if such employee has regular exposure to the hazard dealt with by such standard for the period of his working life.

97. See notes 19-76 supra and accompanying text.

98. Occupational Safety and Health Act § 3(8), 29 U.S.C. \& 652(8) (1976). Section 3(8) provides: "The term occupatioual safety and health standard means a standard which requires conditions, or the adoption or use of one or more practices, means, methods, operations, or processes, reasouably neccssary or appropriate to provide safe or healthful employment and places of employment."

99. The Benzene Court held that its construction of section 3(8) mooted the question of agency cost-benefit analysis:

$\S 3(8)$ requires the Secretary to find, as a threshold matter, that the toxic substance in question poses a significant health risk in the workplace and that a new, lower standard is therefore "reasonably necessary or appropriate to provide safe or healthful employment and placcs of employment." Unless and until such a finding is made, it is not necessary to address the further question whether the Court of Appeals correctly held 
OSHA had merely assumed that some health impairment might be prevented by lowering the exposure limits; it offered no empirical data directly supporting its conclusion. Furtherunore, in fornulating the new standard, the agency had neglected to solicit comments whether the existing 10 ppin standard constituted a significant health threat. 100 Because it concerned the factual heart of the case, this procedural lapse was a strong additional reason for striking down the new regulations.101 The plurahity found that OSHA had failed even to attempt to support its conclusions with substantial evidence. ${ }^{102}$

In contrast to the preexisting levels of exposure at issue in the Benzene case, exposure to cotton dust manifestly constituted a significant health threat in the workplace. The large number of workers afflicted with byssmosis ${ }^{103}$ was expressly cited as one reason for passage of the Act. ${ }^{104}$ In addition, OSHA supported its finding that cotton dust presented a significant health hazard with considerable empirical data. ${ }^{105}$

Thus, with the threshold requirement of section 3(8) satisfied, ${ }^{106}$ the question of whether section $6(b)(5)$ required cost-benefit analysis faced the Court. OSHA had construed the Act as requiring the adoption of the most protective standard possible, limited only by the eco-

that there must be a reasonable correlation between costs and benefits, or whether . . . the Secretary is . . . required by $\S 6(b)(5)$ to promulgate a standard that goes as far as technologically and economically possible to eliminate the risk.

448 U.S. at 614-15.

100. 448 U.S. at 634; Industrial Union Dep't v. Hodgson, 499 F.2d 467, $475-76$ (D.C. Cir. 1974).

What we are entitled to at all events is a careful identification by the Secretary . . . of the reasons why he chooses to follow one course rather than another. . . . [W]hen the Secretary is obliged to make policy judgments where no factual certainties exist or where facts alone do not provide the answer, he slrould so state and go on to identify the considerations he found persuasive.

499 F.2d at 475-76. See generally Environmeutal Defense Fund, Inc. v. Ruckelsliaus, 439 F.2d 584, 598 (D.C. Cir. 1971) ("Courts should require administrative officers to articulate the standards and principles that govern their discretionary decisions in as much detail as possible").

101. 448 U.S. at 623. This aspect of the case supports the observation that "agency decisions mandating reduced exposure to carcinogens are quite vulnerable on procedural grounds." McGarity, supra note 47, at 753. See Pactra Indus. v. Consumer Prod. Safety Comm., 555 F.2d 677, 684 (9th Cir. 1977); Spring Mills, Inc. v. CPSC, 434 F. Supp. 416, 428 (D.S.C. 1977). See also Hess \& Clark, Div. of Rhodia, Inc. v. FDA, 495 F.2d 975, 982 (D.C. Cir. 1974).

102. 448 U.S. at 653 .

103. "Byssinosis, known in its more severe manifestations as "brown lung' disease, is a serious and potentially disabling respiratory disease primarily caused by the inhalation of cotton dust." 101 S. Ct. at 2483 (footnote omitted).

104. S. REP. No. 1282, 91st Cong., 2d Sess. 3 (1970), reprinted in [1971] U.S. Code CoNO. \& AD. News 5177, 5179. See Cotton Dust, $101 \mathrm{~S}$. Ct. at 2482. The Benzene plurality itself noted this fact. 448 U.S. at 646.

105. 101 S. Ct. at 2487,2488 n. 25 .

106. See note 98 supra and accompanying text. 
nomic and technological capabilities of the industry. ${ }^{107}$ Petitionersrepresentatives of the textile industry-urged that the costs of health standards formulated pursuant to section 6(b)(5) must be reasonable in light of the expected benefits. ${ }^{108}$ As in Steadman v. SEC, ${ }^{109}$ the Court began its analysis by focusing on the language of the statute. The words "to the extent feasible" implied that the health standards inust protect employee liealth so far as the prescribed undertaking is "capable of being done." "110 This language deinonstrated that Congress had already balanced the costs and benefits: "Congress itself defined the basic relationship between costs and benefits, by placing the 'benefit' of worker health above all other considerations save those inaking attainment of this 'benefit' unachievable."111 In addition, although section $3(8)$ set forth the general criteria for developing health and safety standards, section 6(b)(5) set forth specific, additional requirements for a subcategory of health standards directed at toxic materials. Therefore, even if section 3(8) could be construed as mandating cost-benefit analysis, the specific provisions of section $6(b)(5)$ override that inandate with stricter standards for toxic materials. ${ }^{112}$

Moving to the second step of its analysis, the Court examined the Act's legislative history and found "general support" for OSHA's interpretation. The Court could find nothing expressly calling for a costbenefit analysis; the absence of such statements indicated a congressional intent that cost-benefit analysis not be used. ${ }^{113}$ Indeed, the only consideration of cost in the history, the language "to the extent feasible", does not require einployers to make the workplace absolutely safe. 114

\section{B. The Question of Cost of Compliance: Deference to Agency Determinations.}

OSHA's determinations concerning the cost of implementation and the economic feasibility of the new standard presented the Court with a close substantive question. After examining two economic feasibility analyses, OSHA adopted the industry-sponsored Hocutt-Thoinas

107. $101 \mathrm{~S}$. Ct. at 2487 .

108. Id. at 2489.

109. 450 U.S. 91 (1981).

110. Cotton Dust, $101 \mathrm{~S}$. Ct. at 2490 (quoting Webster's Third New International DiCTIONARY OF THE ENGLISH LANGUAGE (1976)).

111. 101 S.Ct. at 2490.

112. Id. at 2492; accord Benzene, 448 U.S. at $642-43$.

113. Cotton Dust, 101 S. Ct. at 2493-97.

114. See, e.g., id. at 2494-97; S. REP. No. 1282, 91st Cong., 2d Sess. 58 (1970), reprinted in [1971] U.S. CODE CONG. \& AD. NEws 5222-23. 
study, with some reservations. ${ }^{115}$ OSHA found that the HocuttThomas study overestimated the cost of complying with the regulations by overestimating the number of renovations the industry would need to undertake. However, OSHA also noted that the study based its estimated costs on standards less stringent than the standards actually promulgated."16 In deciding whether the study constituted "substantial evidence" 117 in support of the standard, the Court strictly limited its review. Not only did the Court recognize its general duty to defer to the agency, it also noted that because the statute vested responsibility for determining substantial evidence questions in the courts of appeals, the Court should reverse only when the lower court had "grossly misapplied" the substantial-evidence standard. ${ }^{118}$

The result confirms the Court's deferential stance. The Court uplield the appellate court's finding that the flawed Hocutt-Thomas study met the substantial-evidence standard, noting both the refusal of the textile industry to make available mucl relevant data"19 and the "inherent crudeness" of estimation tools. ${ }^{120}$ Furthermore, the Court re-

115. Cotton Dust at $2497-99 \&$ nn.40-48.

115. Id at 2498-99.

117. It is important to note the standard of review under which the Court actcd. The statute provides that a court must uphold agency regulations if "substantial evidence" supports the rule. 29 U.S.C. $\$ 655(F)$ (1976). In Consolidated Edison Co. v. NLRB, 305 U.S. 197 (1938), the Supreme Court stated that "[s]ubstantial evidence is more than a mere scintilla. It means such relevant evidence as a reasonable mind might accept as adcquate to support a conclusion." Id. at 229.

Traditionally, this standard has been applied to formal rulemaking or adjudication, see Industrial Union Dep't v. Hodgson, 499 F.2d 467, 473 (D.C. Cir. 1974), and at tunes has been held to require that an agency use formal procedure in the absence of other statutory procedural directives. See Verkuil, Judicial Review of Informal Rulemaking, 60 VA. L. REv. 185, 218-22 (1974). However, the Occupational Safety and Health Act explicitly calls for informal rulemaking, 29 U.S.C. $\$ 655(b)(2)$-(4) (1979). The substantial-evidence standard was added to the statute as a compromise to compensate for the deletion of formal rulemaking requirements. H.R. REP. No. 1765, 91st Cong., 2d Sess. 34-5, reprinted in [1970] U.S. CODE CONG. \& AD. NEWS 5228, 5230-31.

One commentator submits that the Act manifests a general congressional policy favoring employee health over cost effectiveness. McGarity, supra note 47, at 784. Howevcr, to the extent that OSHA may be forced to regulate in the absence of precise factual determinations, the substantial-evidence standard suggests that OSHA slould not venture too far beyond the point of uncertainty in fulfilling the general policy of the Act. "Although the 'substantial evidence' standard does not set precise limits on the uncertainty underlying agency factfinding, its presence . . . at the very least implies a congressional reaffirmation of the policy favoring accuracy in agency decisionmaking." Id. at 792 (footnote ountted). "[T]he agency is free to use conservative assumptions im interpreting the data with respect to carcinogens, risking error on the side of over-protection rather than under-protection." Benzene, 448 U.S. at 656. (emphasis added).

118. 101 S. Ct. at 2497 (quoting Universal Camera Corp. v. NLRB, 340 U.S. 474, 491 (1951)). See Mobil Oil Corp. v. FPC, 417 U.S. 283, 292, 310 (1974); FTC v. Standard Oil Co., 355 U.S. 396, 400-01 (1958). The Benzene plurality made no mention of this deference principle.

119. $101 \mathrm{~S}$. Ct. at 2499-500.

120. Id. at 2500 n.54. 
fused to hold that, as a matter of law, the absence of a study exploring the compliance costs of the standard finally adopted constituted grounds for reversal. ${ }^{121}$ Conceivably, this serious inadequacy could have provided a rationale for striking down the standard. Tirus, tile Court's refusal to find OSHA's evidence insubstantial, even though some basis for domg so existed, reflects the Court's growing tendency to defer in practice as well as in theory to agency determinations. ${ }^{122}$

\section{Scientific Uncertainty and the Necessity For Clear Policy Guidelines.}

Both Benzene and Cotton Dust demonstrate the difficulties that unresolved scientific questions pose for a reviewing court. The issue in each case involved "scientific uncertainty" 123 _altiough scientific evidence shows conclusively that certain levels of exposure to benzene and to cotton dust create an appreciable risk of healtir impairment, no such evidence exists concerning the hazards to health created by exposure at the levels estabiished by the new standards. A cost-benefit construction of section $6(b)(5)$ would have prohibited OSHA from setting levels of exposure that result in insufficiently deinonstrable reduction of risk. In contrast, the "feasibility" construction adopted by the Court requires that any risk to employee lealth must be eliminated, within economic and technological limits. The two constructions embody fundanental policy differences: the cost benefit approach allows some impairment of employee health even where the danger could be prevented; the feasibility approach requires that employee healtil be protected beyond the poimt of cost-effectiveness.

Leaving this fundamental policy decision to administrators or courts would be an unconstitutional delegation of Congress' legislative power. Although agencies and courts necessarily make policy determinations, ${ }^{124}$ the Constitution demands that Congress establisil the fun-

121. Id. at 2500. The Court did concede that "a cost estimate based on the standard actually promulgated surely would be preferable ...."Id. The dissent demanded a study based on the adopted standards. Id. at 2507 (Stewart, J., dissentimg).

The Court relied heavily on the " best available evidence" " language of $6(b)(S)$ in its treatment of the study's deficiencies. This reliance is one reason the Court emphasized the industry's refusal to turn over relevant evidence for study. $I d$. at 2500 . The Benzene plurality also recognized the "best available evidence" "language when it stated that "OSHA is not required to support its finding that a significant risk exists with anything approaching scientific certainty." 448 U.S. at 656.

122. See notes $16-19 \mathrm{q}$ supra and accompanying text.

123. 448 U.S. at 690 (Marshall, J., dissentimg).

124. "Fundamentally, our system is not and never has been one of relying exclusively upon the legislative department for all development of policy. The executive and judicial branches of the government are and must be coordinate branches not ouly for carrying out policies determined 
damental guidelines within which the executive or the judiciary must act. ${ }^{125}$ Relying on this principle, Justice Relinquist urged the Court to strike down section 6(b)(5) in both Benzene and Cotton Dust. ${ }^{126}$ In Benzene Relinquist conceded that the nondelegation doctrine has been discredited, ${ }^{127}$ but he correctly argued that even the cases denigrating the doctrine have left enough of it intact to require that Congress estabhish the basic policy to be followed when an agency faces an unresolved scientific question. ${ }^{128}$ 'In drafting $6(\mathrm{~b})(5)$, Congress was faced with a clear, if difficult, choice between balancing statistical lives and industrial resources or authorizing the Secretary to elevate human life above all concerns save massive dislocation in an affected industry." 129 Justice Relınquist beheved Congress had relinquished that choice by imserting the amorphous phrase "to the extent feasible" into section 6(b)(5)..$^{130}$ In short, Congress had enacted no standard, allowing OSHA free reign and thus violating the constitutional mandate for separation of powers.

Justice Relinquist thought the Court's construction of section 6(b)(5) in Cotton Dust perpetuated this constitutional flaw. He interpreted the opinion as allowing cost-benefit analysis under 6(b)(5), but not demanding it. ${ }^{131}$ Under that rule OSHA, without guidance from Congress, would make "a fundamental and most difficult policy choice-whether and to what extent 'tle statistical possibility of future deaths should . . . be disregarded in hight of the econonic costs of preventing those deaths." "132

by the legislative branch but also for determining basic policy." DAvis, supra note $2, \S 3: 7$. See Benzene, 448 U.S. at 673-75 (Rehnquist, J., concurring in judgment).

125. "I recognize without hesitation that judges do and must legislate, but they can do so only interstitially; they are confined from molar to molecular motions." Southern Pacific Co. v. Jensen, 244 U.S. 205, 221 (1916) (Hohnes, J. dissenting); see McGarity, supra note 47, at 784.

126. 448 U.S. at $685-86$ (Rehnquist, J., concurring in judgement). For two cases in which the Court invalidated statutes as unconstitutional delegations of the legislative power, see Schechter Poultry Corp. v. United States, 295 U.S. 495 (1935); Panama Refining Co. v. Ryan, 293 U.S. 388 (1935). Considerable doubt exists as to whether these cases are still good law. See note 127 infra and accompanying text.

127. E.g., FEA v. Algonquir SNG, Inc., 426 U.S. 548 (1976); United States v. Southwestern Cable Co., 392 U.S. 157 (1968); Permian Basin Area Rate Cases, 390 U.S. 747 (1968); Amcrican Trucking Ass'ns, Inc. v. Atchison, T.\&S.F.RY., 387 U.S. 397 (1967); Falsey v. Mallonee, 332 U.S. 245 (1947); DAvis, supra note 2, \& 3:6 ("That major governmental policy is often made without significant statutory guidance is such a commonplace proposition that three hundred examples could easily be given from cases decided by the Supreme Court").

128. 448 U.S. at 674-75 (Rehnquist, J., concurring in judgment).

129. Id. at 685 .

130. "That Congress chose, intentionally or unintentionally, to pass this difficult choice on to the Secretary is evident from the spectral quality of the standard it selected . . ." Id.

131. Colton Dust, $101 \mathrm{~S}$. Ct. at 2508 (Rehnquist, J., dissenting).

132. Id. at 2509 . 
Had the Cotton Dust majority so construed section 6(b)(5), Justice Rehnquist's nondelegation argument should have prevailed. The choice between cost-benefit and feasibility analysis-involving as it does a determination of the relative importance of money and human lives-is indeed a fundamental policy decision. However, the majority expressly discounted Justice Rehnquist's reading of its opinion. ${ }^{133}$ The Court held that section 6(b)(5) requires OSHA to limit employee exposure to cotton dust to the extent that such a reduction is feasible or, in other words, to a point bounded only by unavoidable technological and economic limitations. The Court based this interpretation on a reasonable reading of the plain words of the statute. Given the dictionary meaning of "feasible," 134 the phrase "to the extent feasible" leaves little room for injecting a cost-benefit eleinent into the statute. Admittedly, both the statute and the legislative history could describe more clearly the policy Congress intended. However, even if a law can reasonably be construed as providing for an unconstitutional delegation of legislative power to an agency, precedents show that a court may render the delegation constitutional by construing narrowly the discretion granted the agency. ${ }^{135}$ If section $6(\mathrm{~b})(5)$ was intended to require a cost-benefit approach, the Court so narrowed the agency's discretion.

\section{FCC V. WNCN LISTENERS GUILD: DEFERENCE AND DEREGULATION}

\section{A. The Decision.}

FCC v. WNCN Listeners Guild ${ }^{136}$ is the latest in a series of cases stemming from the tension between the need for government regulation of the broadcast imdustry ${ }^{137}$ and the principle that broadcasting is a free enterprise governed largely by a competitive market. ${ }^{138}$ Specifically, the Court decided in WNCN that the Federal Communications Commission, in renewing a radio station's license, need not consider the station's change in entertainment programming despite events indicating that the change fails to serve the "public interest, convenience,

133. $Y d$. at $2506 \mathrm{n} .75$.

134. See note 110 supra and accompanying text.

135. Kent v. Dulles, 357 U.S. 116 (1958); DAVIs, supra note 2, § 3:13.

136. 450 U.S. 582 (1981).

137. See, e.g., FCC v. National Citizens Comm. for Broadcasting, 436 U.S. 775, 799 (1978); Red Lion Broadcasting Co. v. FCC, 395 U.S. 367 (1969); National Broadcasting Co. v. United States, 319 U.S. 190 (1943).

138. See FCC v. Sanders Bros. Radio Station, 309 U.S. 470, 475 (1940); Federal Communications Act, 47 U.S.C. § 153(h) (1976). 
and necessity." 139 In a series of cases decided in the 1970 s, ${ }^{140}$ the Court of Appeals for the District of Columbia Circuit held that the publicinterest standard comprehends changes in entertainment programming. The court held that events such as significant public protest against a change in entertainment format constitute prima facie evidence that the change fails to serve the public interest. On a showing of such evidence, the court further held that section 309(d)(1) of the Federal Communications Act (the Act) ${ }^{141}$ requires the FCC to conduct a hearing to determine the merits of the change. ${ }^{142}$ This construction of the Act, labelled the "format doctrine," was applied only grudgingly by the FCC. 143

In 1976, pursuant to its rulemaking authority, ${ }^{144}$ the $\mathrm{FCC}$ sought comments on and inquired into its role in the review of entertainmentformat changes. ${ }^{145}$ As a result of this study, the Commission issued a Memorandum Opinion and Order (the Order) ${ }^{146}$ in which it rejected the format doctrine. The FCC found that the Act requires no review of

139. 450 U.S. at 604; Federal Communications Act, 47 U.S.C. 309(a) (1976). That section provides:

Subject to the provisions of this section, the Commission shall determine, in the case of each application filed with it to which section 308 of this title applies, whether the public interest, convenience, and necessity will be served by the granting of such application, and, if the Commission, upon examination of sucls application and upon consideration of such other matters as the Commission may officially notice, shall find that public interest, couvenience, and necessity would be served by the granting thereof, it shall grant sucls application.

Section 309(d)(1) provides that any party in interest may petition the Commission to deny an application for license transfer or renewal, but the petition must contain specific allegations of fact sufficient to show that granting the application would be "prima facie inconsistent" with the public interest.

140. Citizens Comm. to Save WEFM v. FCC, 506 F.2d 246 (D.C. Cir. 1974) (en banc); Cítizens Comm. to Keep Progressive Rock v. FCC, 478 F.2d 926 (D.C. Cir. 1973); Lakewood Broadcasting Serv., Inc. v. FCC, 478 F.2d 919 (D.C. Cir. 1973); Citizens Comm. to Preserve the Voice of Arts v. FCC, 436 F.2d 263 (D.C. Cir. 1970). See also Hartford Commurications Comm. v. FCC, 467 F.2d 408 (D.C. Cir. 1972).

141. 47 U.S.C. \& 151 (1976).

142. "[W] here a significant sector of the listening community, in opposition to the assignment [or renewal of the station's license], protests the loss of such a format by substantial factual allegations that it is both unique and financially viable, the statute requires that the Commission hold a learing." WNCN Listeners Guild v. FCC, 610 F.2d 838, 841 (D.C. Cir. 1979) (en banc), rev'd, 450 U.S. 582 (1981). The court stressed that "the Commission's obligation to consider format issues arises only when there is strong prima facie evidence that the market has in fact broken down." If there exists a substitute in the area for the abandoned entertaimment format, public protest is weak, supporters of the format are few or it is not financially feasible to continue the format, then "[n]o public interest issue is raised. . . . [G]enerally the existence vel non of these factors can be determined without the need for a hearing." Id. at 851 .

143. Id. at $849-50$.

144. 47 U.S.C. $\S 303(r)$ (1976).

145. Changes in the Entertainment Formats of Broadcast Stations, 57 F.C.C.2d 580 (1976).

146. 60 F.C.C.2d 858 (1976), reconsideration denied, 66 F.C.C.2d 78 (1977). 
entertainment-format changes, that such review engenders serious administrative problems, and that it stifles experimentation in radio programming. Emphasizing free-market philosophy, the FCC took the position that competition, rather than government regulation, is the best means of achieving variety in entertainment formats. ${ }^{147}$

A number of citizens groups wishing to preserve certain entertainment formats petitioned the Court of Appeals for the District of Columbia Circuit for review of the Order. The court struck down the Order, although it agreed with the FCC that, as a rule, market forces generate so many different formats that one station's alteration of its entertainment programming does not harm the public interest. ${ }^{148}$ The court also recognized, however, that the radio market falls short of perfectly reflectimg listener preferences. Owing to the dynamics of advertising, the preferences of those groups with large incomes tend to outweigh the desires of less influential groups such as children and the elderly. ${ }^{149}$ Stations catering to high-income groups inay frustrate the Act's goal of securing "the maximum benefits of radio to all the people of the Umited States." 150 Thus, when public protest signals that the market has failed to meet listener preferences, the FCC must investigate whether a station's format change in fact conflicts witl the public interest.

Supreme Court cases dealing with rulemaking and other action by the FCC call for substantial deference to the Commission. ${ }^{151}$ WNCN followed this tradition of deference. The Court required only that the FCC provide "a rational explanation" to support its argument that free coinpetition is the best means of achieving diversity in entertainment formats. ${ }^{152}$ Given the broad discretion afforded the FCC by Congress in deciding what serves the public interest, courts must refrain from

147. 60 F.C.C.2d at $862-66$.

148. 610 F.2d at 851 ; see note 115 supra.

149. 610 F.2d at 851 .

150. National Broadcasting Co. v. United States, 319 U.S. 190, 217 (1943).

151. See FCC v. National Citizens Comm. for Broadcasting, 436 U.S. 775 (1978); Coluunbia Broadcasting Sys., Inc. v. Democratic Nat'l Comm., 412 U.S. 94 (1973); Red Lion Broadcasting Co. v. FCC, 395 U.S. 367 (1969); Storer Broadcasting Co. v. FCC, 351 U.S. 192 (1956); FCC v. WOKO, Inc., 329 U.S. 223 (1946); National Broadcasting Co. v. United States, 319 U.S. 190 (1943); FCC v. Sanders Bros. Radio Station, 309 U.S. 470 (1940).

152. 450 U.S. at 595-96. Accord FCC v. National Citizens Comm. for Broadcasting, 436 U.S. 775, 802-03 (1978) (the FCC's interpretation and resulting regulations inust be upheld if not irrational). Like WNCN, National Citizens involved regulations based on the FCC's experienced judgment, rather than on hard empirical data. The Court found the regulations reasonable, despite the lack of enpirical evidence, because of a waiver provision which would ameliorate adverse consequences if the Commission's judgment proved wrong. The FCC's entertainmentformat rules considered in $W N C N$, however, contain no waiver provision. See notes 134-41 infra and accompanying text. 
substituting their own opinions for those of the agency. The Supreme Court found that the court of appeals had effected such a substitution. The FCC and the court of appeals agreed that market forces ensure diversity in most instances, but they differed on the appropriate steps in situations not following the norm. Barring an irrational conclusion by the FCC, case law demanded that the Commission's view prevail. Because the FCC's position reasonably balanced the need for diversity in programming against the policy of allowing stations discretion in structuring their formats, the Supreme Court uplield the FCC's determination. ${ }^{153}$

\section{B. The Dissent: In Favor of Flexibility.}

In dissent, Justice Marshall supported the flexible approach of the format doctrine and articulated three objections to the majority result. ${ }^{154} \mathrm{He}$ first argued that both the FCC and the majority misunderstood the purpose and effect of the format doctrime. ${ }^{155}$ Rather than being a vehicle for strict regulation by the government, 156 the doctrine compleinents the free-inarket systein and compels review of format changes only when substantial prima facie evidence, such as public protest, suggests that the narket has failed to produce adequate diversity. The court of appeals' opinion confirms this reading of the format doctrime. ${ }^{157}$ The majority opinion proceeded on the incorrect premise that

153. 450 U.S. at $595-96$.

154. Id. at 604-20 (Marshall, J., dissenting). An additional aspect of the majority's opinion not discussed in the dissent merits attention. The court of appeals raised but did not address the issue of the FCC's failure to disclose a staff study on the market control of formats before issuing the Order. In his concurrence, Judge Bazelon emphasized the FCC's "almost cavalicr disregard for the public's right to comment on the critical data and inethodology supporting the Commission's finding . . ." 610 F.2d at 858. He would have struck down the new rule solely for this procedural error. $I d$. at 858-59. The court of appeals inajority did note the importance of "adversarial testing" of an agency's data and conclusions with regard both to substantive accuracy and procedural fairness. Because it struck down the order on substantive grounds, however, the court saw no need to decide whether this procedural flaw alone invalidated the Order. Id. at 846-47, 846 n.24. The Suprene Court dismissed this issue with the conclusory statement, "We . . . do not consider the action of the Commission, even if a procedural lapse, to be a sufficient ground for reopening the proceedings before the Commission." 450 U.S. at 591 n.22.

The Court's treatment of the procedural flaw in $W N C N$ contrasts with its action in Industrial Umion Dep't v. American Petroleum Institute, 448 U.S. 607 (1980) (Benzene). In Benzene OSHA neglected to call for comments regarding the new benzene standard before the standard's promulgation. The Court cited this procedural lapse as a major reason for striking down the standard. Id. at 623-25. See note 101 supra and accoinpanying text. Viewcd in light of the emphasis placed on the procedural question in Benzene, the Court's summary dismissal of the identical issue in $W N C N$ is at best questionable.

155. 450 U.S. at 605-07.

156. Sce note 85 supra and accompanying text.

157. 610 F.2d at 851 . 
the fornat doctrine entails significant government involveinent in radio broadcasting. ${ }^{158}$

Justice Marshall's second objection to the $W N C N$ result was the Court's failure to explain the different treatment of entertainment and nonentertainment programming changes. During licensing proceedings, the FCC considers listener complaints about nonentertainment forinat changes only. ${ }^{159}$ The majority attempted to justify the distinction by stating that the difference was imsignificant. It observed that an evidentiary hearing concerning changes in nonentertainment formats can be obtamed " only when it appears that the licensee has abused its broad discretion by acting unreasonably or in bad faith.' "160 However, if a listener coinplaims that a broadcaster's discontinuation of a particular entertainment format is unreasonable or in bad faith, the Order precludes any investigation by the FCC into the matter. ${ }^{161}$

Justice Marshall's third objection was that "safety valve" procedures, which enable an agency to consider applications for exemptions from general rules, are necessary for an agency to proceed with fairness in complex areas. ${ }^{162}$ Because the Order allowed for no exceptions, the Justice would have struck it down. ${ }^{163}$ Although several of the decisions cited by Justice Marshall do emphasize the importance of the power to waive general rules in particular cases, they fall short of establishing a settled doctrime that all rules must contain a waiver provision.

For instance, in National Broadcasting Co. v. United States ${ }^{164}$ the Court explored the validity of regulations that conclusively forbade the issuance or renewal of licenses to stations with certain network ties. In a passage Justice Marshall used as support for his safety-valve argument, the National Broadcasting Court stated:

The Commission ... did not bind itself inflexibly to the licensing policies expressed in the Regulations. In each case that comes before it the Commission must still exercise an ultimate judgment whether the grant of a license would serve the "public interest, convemence, or necessity." If time and changing circumstances reveal that the "public interest" is not served by application of the Regulations, it must be assumed that the Commission will act in accordance with its

158. 450 U.S. at $601-03$.

159. See Community Television of S. Cal., 72 F.C.C.2d 349 (1979); Mississippi Auth. for Educ. TV, 71 F.C.C.2d 1296 (1979); Central Cal. Communications Corp., 70 F.C.C.2d 1947 (1979); Channel 20, Inc., 70 F.C.C.2d 1770 (1979).

160. 450 U.S. at 602 (quoting Mississippi Auth. for Educ. TV, 71 F.C.C.2d 1296, 1308 (1979)).

161. See 450 U.S. at 616-17 (Marshall, J., dissenting).

162. Id. at 609-10.

163. Id. at 607-17.

164. 319 U.S. 190 (1943). 
statutory obligations. ${ }^{165}$

This passage concerns the FCC's continuing duty to consider the licensing pohicies embodied in the regulations and to revise the regulations if experience shows thein to be ineffective or detrimental. The regulations theinselves allowed for no such flexibility. ${ }^{166}$ If a station met the criteria, the rule required the FCC to deny its application for licensing. Thus, rather than furnishing precedent for Justice Marshall's arguinent, National Broadcasting instead supports the result of WNCN by upholding regulations that allowed for no exceptions. ${ }^{167}$

A second case rehed upon by Justice Marshall, however, supports the safety-valve argument. United States $v$. Storer Broadcasting Co. ${ }^{168}$ concerned an FCC regulation prohibiting the grant of a license to a television station whose owner had a substantial interest in five other stations. The Court of Appeals for the District of Columbia Circuit struck down the regulation as violative of an applicant's right to a section 309(a) ${ }^{169}$ hearing. The Supreine Court reversed, holding that section 309 does not autoinatically guarantee a hearnig to disappointed apphicants. Nevertheless, the Court noted that the regulations provided the applicant with an opportumity to obtain a liearing by showing that the basic premise of the regulation did not apply to his case. The Court einphasized the importance of this waiver provision in upholding the regulation. ${ }^{170}$

Although the Court in Storer and National Broadcasting noted the flexible eleinents of the FCC regulations, those elements were by no means the chief rationale for the decisions. ${ }^{171}$ The cases fall short of establishing that waiver provisions are necessary coinponents of rules

165. Id. at 225 (quoted by Justice Marshall in WNCN Listeners Guild v. FCC, 450 U.S. at 610).

166. A Commission statement cited in National Broadcasting indicates the context of the passage emphasized by Justice Marshall: "The problems in the network field are interdependent, and the steps now taken may perhaps operate as a partial solution of problems not directly dealt with at this time. Such problems may be examined again at some future time after the regulations here adopted have been.given a fair trial." FEDERAL COMMUNICATIONS COMMISSION, REPORT ON ChaIN BROAdCasting 88 (1941), quoted in 319 U.S. at 225 (emphasis added).

167. FCC v. Sanders Bros. Radio Station, 309 U.S. 470 (1940), also conflicts with the "safetyvalve" argument. In that case the Supreme Court reversed the demand of the Court of Appeals for the District of Columbia Circuit that the FCC cousider the economic impact that hicensing one station may have on another. Unlike the situation in $W N C N$, however, the Act provided fairly explicit support for the FCC's interpretation. With its emphasis on broadcasting as a free enterprise, the Act discouraged the FCC from insulating stations from fair competition. 47 U.S.C. $\S 153(\mathrm{~h})(1976)$.

168. 351 U.S. 192 (1956).

169. 47 U.S.C. \& 309(a) (1976).

170. 351 U.S. at 205.

171. 450 U.S. at 601 n.44. 
that are based on experience, rather than on hard facts, and that deal with complex fields. Although Justice Marshall's argument has some merit, the absence of a waiver provision cannot alone justify the invalidation of an agency rule. ${ }^{172}$

\section{The Law-Policy Distinction: Blind Deference.}

The most serious flaw in the $W N C N$ decision is the Court's failure to justify its characterization of the FCC regulation as "pohcy." Neither the Supreme Court nor the court of appeals explained their characterizations of the rule. The court of appeals held that the format doctrine "represents, not a policy, but rather the law of the land . . .."173 This triggered the court's less deferential standard of review, which im turn justified striking down the Order. ${ }^{174}$ The Supreme Court identified the regulation as policy, dismissing the court of appeals' characterization with the broad statement that "the public-interest standard of the Act [is] 'a supple mstrument for the exercise of discretion by

172. The Court rejected a similar flexibility argument challenging agency regulations in Schweiker v. Gray Panthers, 101 S.Ct. 2633 (1981). Pursuant to its rulemaking authority under the Social Security Act, 42 U.S.C. $\$ 1396 a(a)(17)(B)$ (1976), the Secretary of Health and Human Services established rules determining ehgibility for Medicaid benefits. One such rule provided that the states paying those benefits may "deem" the income of a non-applymg spouse to be available to the spouse applying for benefits, thus decreasing or eliminating the applicant's eligibility. 42 C.F.R. $\$ 435.734$ (1980). This "deeming" was allowed even though the spouses maintained separate quarters, as when one spouse lived in a health care institution. The Gray Panthers organization sued to strike down the regulation, alleging that it conflicted with the statutory requirement that only imcoine actually available to the applicant may be considered in determining Medicaid eligibility. See 42 U.S.C. 1396a(a)(17) (1976). The Supreme Court, reversing the Court of Appeals for the District of Columbia Circuit, upheld the regulations. Emphasizing the great deference due the Secretary's interpretation of the statute, the Court agreed with the Secretary that the statute conclusively presumes that one spouse's income is available to the other although the two may live separately. $101 \mathrm{S.Ct}$. at 2643.

In a dissent joined by Justices Brennan and Marshall, Justice Steveus agreed with the reasoning of both the district court and the court of appeals. He repeated the court of appeals' einphasis on those portions of the legislative history that the presumption that spousal income is available depends on the spouses' cohabitation. Id. at 2643, 2644 n.4 (Stevens, J., dissenting). He stated: "Congress intended a flexible approach to apply in situations in which the basic assumption of cohabitation could not be made." Id. at 2644. "[T]he premise that spouses pool income and resources should not apply when one spouse is institutionalized." Id. at 2644 n.4. Nevertheless, just as the majority rejected the flexibility argument in $W N C N$, it interpreted the statute in Gray Panthers as precluding any such individualized factual determination.

173. WNCN Listeners Guild v. FCC, 610 F.2d 838, 854, rev'd, 450 U.S. 582 (1981) (emphasis in original).

174. 610 F.2d at 854-55 ("This court has neither the expertise nor the constitutional authority to inake 'policy' as that word is commonly understood . . . . But in matters of interpreting the 'law' the final say is constitutionally committed to the judiciary."); see W. GELLHORN, C. BYSE \& P. Strauss, Administrative Law-Cases and Comments 315 (7th ed. 1979); M. HarT, JR., \& A. Sacks, The Legal Process: Basic Problems in the Making and Application of Law 1345-47 (tenth ed. 1958). 
the expert body which Congress has charged to carry out its legislative policy." "175 Because the characterization of a regulation as policy rather than law leads a reviewing court to accord it greater deference, the actual nature of the FCC regulation is highly relevant in evaluating the soundness of the $W N C N$ result.

In Chrysler Corp. v. Brown ${ }^{176}$ the Suprene Court dealt with the law/policy distinction in deciding whether a regulation constituted "law" within the meaning of the Trade Secrets Act. ${ }^{177}$ Chrysler Corporation sued to enjoin the Department of Defense froin releasing to the public information that the petitioner had given the Department pursuant to equal employment opportunity requireınents. Chrysler, citing a provision of the Trade Secrets Act prohibiting disclosure of information "except as provided by law," 178 argued that the regulations ${ }^{179}$ pursuant to which the Departinent would release the information were not law. The Supreine Court agreed, distinguishing "substantive rules" from general statements of policy by stating that a substantive rule is one "'affecting individual rights and obligations." "180 If the agency has the power to promulgate the substantive rule and follows the required procedures, then the rule carries "the 'force and effect of law." "181

The courts of appeals have elaborated on the attributes of regulations that constitute policy rather than law. Policy merely describes the basic standards that the agency will apply in deciding future substantive questions. Policy is not "finally determinative of the issues or rights to which it is addressed"; it "inust leave the agency free to exercise its discretion and must not establish a "binding norm." "182 If a

175. WNCN Listeners Guild v. FCC, 450 U.S. 582, 593 (1981) (quoting FCC v. Pottsville Broadcasting Co., 309 U.S. 134, 138 (1940)).

176. 441 U.S. 281 (1979).

177. 18 U.S.C. \& 1905 (1976).

178. $I d$.

179. 41 C.F.R. $\$ \S 60.40-1$ to $.40-4$ (1978) (current version at 41 C.F.R. $\$ \S 60-40.1-.4$ (1981)).

180. 441 U.S. at 302.

[I]n Morton v. Ruiz, 415 U.S. 199 (1974), we noted a characteristic inherent in the concept of a "substantive rule." We described a substantive rule- or a "legislative-type rule,"-as one "affecting individual rights and obkgations." This characteristic is an important touchstone for distinguishing those rules that may be "binding" or have the "force of law."

441 U.S. at 302 (citations omitted).

181. 441 U.S. 281, 302 (quoting Morton v. Ruiz, 415 U.S. 199, 236 (1974)). See Batterton v. Francis, 432 U.S. 416, 425 n.9 (1977); Foti v. Immigration and Naturalization Serv., 375 U.S. 217, 223 (1963); United States v. Mersky, 361 U.S. 431, 437-38 (1960); Atchison, T. \& S.F. Ry. v. Scarlett, 300 U.S. 471, 474 (1937).

182. Burroughs Wellcome Co. v. Schweiker, 649 F.2d 221, 224 (4th Cir. 1981); Regular Common Carrier Conference of the Am. Trucking Ass'ns v. United States, 628 F.2d 248, 251-52 (D.C. Cir. 1980); American Bus Ass'n v. United States, 627 F.2d 525, 529 (D.C. Cir. 1980). See Farm- 
regulation establishes a strict rule that finally determines an issue and leaves the agency no discretion, then that regulation is law.

The FCC's entertainment programming regulation, in liglit of the above criteria, is law rather than policy. The regulation is determinative on the issue of entertainment programming changes; it precludes the FCC from considering whether a change in entertainment programming should prohibit the assignment or renewal of a station's license. Rather than speaking in terms of presumptions, ${ }^{183}$ or providing opportunities for decisions on an individual basis, ${ }^{184}$ the regulation in $W N C N$ conclusively determines that no cliange in entertainment format affects the "public interest, convernence, or necessity" so adversely that it prevents the grant or renewal of a station's license. In short, the regulation precludes the Commission from exercising its informed discretion in the various entertainment-format cases that coine before it.

Because the reguilation significantly affects "individual riglits," it is a "substantive rule" within the ineaning of the law/policy test estabhished in Chrysler Corp. v. Brown. ${ }^{185}$ The FCC affords listeners no reinedy when a station abandons a particular entertainment fornat to their detriment. Entertainment programming conveys the "social, political, esthetic, inoral, and other ideas and experiences" to which the first amendment guarantees access. ${ }^{186}$ The FCC regulation stifles listener remedies when a station's change of fornat impinges upon that first amendment right. The regulation very definitely affects "individual rights"- sensitive first amendment rights-an attribute that invests the regulation with "the force and effect of law."

Whether the regulation would have survived less deferential scrutiny, the Court's flawed conception of deference endangers first ainend-

land Indus., Inc. v. United States, 642 F.2d 208, 210, (7th Cir. 1981); Guardian Fed. Sav. \& Loan Ass'n v. FSLIC, 589 F.2d 658, $666-67$ (D.C. Cir. 1978); Pacific Gas \& Elec. Co. v. FPC, 506 F.2d 33, 38 (D.C. Cir. 1974).

183. See Regular Common Carrier Conference of the Am. Trucking Ass'ns v. United States, 628 F.2d 248, 251 (D.C. Cir. 1980).

184. See Guardian Fed. Sav. \& Loan Ass'n v. FSLIC, 589 F.2d 658, 667 (D.C. Cir. 1978). The Guardian court also stated that if a rule lays down "stringent substantive commands," it constitutes law even if it has "some provision for discretionary waiver." Id. "A waiver provision is no substitute for the exercise of informed discretion in the various cases arising under the regulation." $I d$. at 667 n.33. See WAIT Radio v. FCC, 418 F.2d 1153, 1157 (D.C. Cir. 1969); Texaco, Inc. v. FPC, 412 F.2d 740, 744 (3d Cir. 1969).

185. 441 U.S. 281 (1979). See notes 180-81 supra and accompanying text.

186. Red Lion Broadcasting Co. v. FCC, 395 U.S. 367, 390 (1969).

[T]he people as a whole retain their interest in free speech by radio and their collective right to have the medium function consistently with the ends and purposes of the First Amendment. It is the right of . . listeners, not the right of the broadcasters, which is parainount. . . . It is the right of the public to receive suitable access to social, political, Id. esthetic, moral, and other ideas and experiences which is crucial here. 
ment rights. Given the regulation's inflexible nature and restriction of first amendment rights, the Court was obligated to review the regulation more rigorously than a non-binding statement of policy. Instead, in keeping with the tenaciously deferential stance adopted in other recent cases, ${ }^{187}$ the Supreme Court assumed that it owed extreme deference to the Commission and neglected to examine the validity of that assumption.

\section{CONCLUSION}

The Supreme Court decisions of 1980 and 1981 clearly inanifest a tendency to defer in practice as well as in thcory to agency rulemaking and adjudication. This tendency is in marked contrast to the nore rigorous review of the past decade and in some instances produces questionable results. In Strycker's Bay, for example, the Court used the deference principle to justify its superficial review of the agency's decision, and in $W N C N$ the Court's mistaken basis for affording extreme deference to the Commission produced cursory review of a regulation restricting first amendment rights. That the judiciary should generally defer to agency determinations is a sound and established principle. ${ }^{188}$ Nonetheless, the Court's indiscriminate and even careless adlierence to this principle not only detracts from the soundness of the particular cases but also upsets the balance between the legislative, executive, and judicial branches of government. Only through reasoned application of deference can the judiciary achieve botl meaningful review of agency decisions and the respect due those decisions.

Benjamin Eagles Fountain, III

187. See notes 19-77 supra and accompanying text.

188. See Woodward \& Levin, In Defense of Deference: Judicial Review of Agency Action, 31 AD. L. REv. 329 (1979). 